\title{
Sexual Assault: The Crisis That Blindsided Higher Education
}

\author{
Sona Gala ${ }^{1}$, Arthur Gross-Schaefer ${ }^{2}$ \\ ${ }^{1}$ Adjunct Professor, College of Business Administration, Department of Marketing and Business Law and Department \\ of Entrepreneurship, Loyola Marymount University, 1 LMU Drive, MS-8285, Los Angeles, California, 90045-2659 / \\ Attorney at Law, Orange County, California \\ 2 Professor/Rabbi/JD, CPA (inactive), MAHL, DD (honoris causa) / College of Business Administration, Loyola \\ Marymount University, Los Angeles, California 90045 / Community Shul of Montecito and Santa Barbara / Avi \\ Schaefer Fund. \\ Correspondence: Sona Gala, Adjunct Professor, College of Business Administration, Department of Marketing and \\ Business Law and Department of Entrepreneurship, Loyola Marymount University, 1 LMU Drive, MS-8285, Los \\ Angeles, California, 90045-2659 / Attorney at Law, Orange County, California
}

Received: May 18, 2016

Accepted: May 31, 2016

Available online: June 24, 2016

doi:10.11114/ijsss.v4i8.1692

URL: http://dx.doi.org/10.11114/ijsss.v4i8.1692

\begin{abstract}
This paper begins by examining the history of university oversight of sexual assault cases and why sexual assault has become such a problem on college and university campuses. Next the paper will examine existing laws that govern how colleges handle sexual assault cases. Subsequently, this article will discuss the loopholes in existing laws that have allowed institutions of higher learning to not only ignore the problem of sexual assault, but also underreport incidents of sexual assault. Current proposed legislation and administrative actions will be explored that attempt to close these loopholes forcing universities to answer for their failure to handle sexual assault cases properly and revamp their existing policies to better protect victims of sexual assault. Finally, the authors provide potential solutions for what is likely the next big crisis in higher education.
\end{abstract}

Keywords: women, sexual assault, rape, colleges, universities.

\section{Introduction}

Emma Sulkowicz was sexually assaulted in 2012 during her sophomore year at Columbia University. The perpetrator was someone she knew. When Emma reported the incident to school officials, the university investigator took inaccurate and incomplete notes, there were numerous hearing postponements, and school officials repeatedly told Emma that she could not discuss her case with anyone. She felt isolated, alone, and afraid (Perez-Pena \& Taylor, 2014).

When Emma's case was finally heard by a panel that was poorly trained in handling sexual assault cases, she was forced to answer questions that seemed to indicate that the panel had little to no knowledge about how sexual assaults occur. For example, in Ms. Sulkowicz words, she was asked repeatedly by a university official how the sex act IMs. Sulcowicz endured was physically possible. She then heard the accused student testify that she had "imagined he coerced her" into having sex. Worse than the panel's failure to understand what happened to Ms. Sulkowicz, was their dismissal of her case. The University not only dismissed Sulcowicz's case, but two other claims filed by students for sexual assault against the same perpetrator (Perez-Pena \& Taylor, 2014). The university's handling of the case and its adjudication process left Sulcowiz traumatized. In her words, "Has anything ever happened to you that was just so bad that you felt like you became a shell of a human being (Perez-Pena \& Taylor, 2014)."

Sulcowicz's story is not an isolated incident. She recently became part of a group of women at Columbia who were profiled in Columbia's student magazine, The Blue and White. The article addressed how women, including Sulcowicz were sexually assaulted at Columbia and detailed their frustrated searches for help and justice from a university system that was unwilling to help or even listen (Perez-Pena \& Taylor, 2014).

In 2013, Lena Sclove, a student at Brown University, filed a complaint with the school alleging that a fellow student, Daniel Kopin, had sexually assaulted and choked her. According to Sclove, University officials led her to believe that she had a choice of either filing a complaint with the school or going to the local police, but she could not do both. Based on existing legislation, Sclove should have been told she had the right to file complaints with both the school and 
local police. Without knowing all her options, Sclove elected to file a complaint with Brown. After hearing her case, a university adjudication panel recommended that Kopin be suspended for two years. This would have allowed Sclove to complete school without having to see Kopin again. A Dean at the University, who did not attend the hearing, reduced the suspension to one year. Ultimately, Kopin only spent one semester completely off campus. After enduring this ordeal and discovering Brown did not give her accurate information about her rights, Sclove filed a complaint with the Department of Education alleging, among other things, that she was misinformed of her right to file complaints with Brown University and local law enforcement (Kingkade, 2014).

Sulcowicz and Sclove's cases are just two examples of the growing number of sexual assault cases that have been mishandled by institutions of higher education. There is minimal evidence to suggest that sexual assaults are more or less prevalent on university and college campuses than in the past, but schools are now being forced to address an issue that they have ignored for far too long (Perez-Pena \& Taylor, 2014). Why are universities and colleges suddenly being forced to confront the issue of sexual assault? More and more victims are coming forward; moreover, activists fighting for victims' rights have become more and more tech savvy, using social media to their advantage (Perez-Pena \& Taylor, 2014). For example, the Rape, Abuse, \& Incest National Network (RAINN), dedicated to preventing sexual violence on college campuses, can be found on social media sites such as Facebook Twitter, and Instagram. RAINN is the nations largest anti-sexual assault organization. RAINN allows users to connect through social media sites such as Facebook and Twitter to help victims of sexual violence find assistance programs and share their stories (RAINN, 2014). Individuals such as Wagatwe Wanjuti, a victim of sexual assault, utilized social media, online organizing, and blogging to launch a petition to ensure that the Department of Education holds schools accountable for failing to comply with Title IX. In particular, Wanjuti was able to hold her former alma mater, Tufts University, accountable for failing to provide prompt remedial measures to address complaints of sexual harassment on campus (Bridget Todd, 2015). In addition to their use of technology, activists continue to use their tried and true protest techniques effectively. At Columbia, where Lena Sulowicz's case took place, student activists placed red tape over their mouths and attempted entry into an event for prospective freshman. Activists handed out flyers encouraging prospective students to push university administration for resources to be available to victims of sexual assault (Perez-Pena \& Taylor, 2014).

Voices of victims and activists have not only forced universities and colleges to take notice, but the government has also taken note. On May 1, 2014, the Education Department's Office for Civil Rights ("OCR") published a list of colleges and universities under investigation for potential violations of federal law based on their potential mishandling of sexual assault claims. The list began with fifty-nine universities, but rapidly increased to over eighty-five schools in the span of six months (Anderson, 2014). Cases such as those at Columbia, Brown, and many other universities, along with the Department of Education's probe into numerous colleges' and universities' mishandling of sexual assault cases, demonstrate that institutions of higher education to date, have done a poor job of addressing the issue of sexual assault and/or violence against women.

The statistics regarding colleges' and universities' failure to protect their students from sexual assault speak for themselves. One in five women will be sexually assaulted while attending a college or university today in America (Gray, 2014). Commenting on this staggering statistic, Vice President Joe Biden recently said in an interview with TIME Magazine: "If you knew your son had a $20 \%$ chance of being held up at gunpoint, you'd think twice before dropping your kid off." "Well, my God, you drop a daughter off, it's a 1 in 5 , she could be raped or physically abused? It is just outrageous (Gray, 2014)" While the one in five statistic is at the very least unnerving, what is even more alarming is that many colleges and universities are reporting zero rapes on their campuses (a 2009 investigation by the Center for Public Integrity found that seventy-seven percent of colleges and universities reported an unbelievable zero rapes in 2006 (Gray, 2014). The question then arises that if statistics demonstrate that one in five women on college and university campuses have been sexually assaulted, how are seventy-seven percent of colleges and universities reporting zero rapes on their campuses?

To answer this question, the initial focus of this this paper will examine the history of university oversight of sexual assault cases and why sexual assault has become such a problem on college and university campuses. Next the paper will examine existing laws that govern how colleges handle sexual assault cases. Subsequently, this article will examine the loopholes in existing laws that have allowed institutions of higher learning to not only ignore the problem of sexual assault, but also underreport incidents of sexual assault. Current proposed legislation and administrative actions will be explored that attempt to close these loopholes forcing universities to answer for their failure to handle sexual assault cases properly and revamp their existing policies to better protect victims of sexual assault. Finally, the authors provide potential solutions for what are likely the next big crises in higher education.

\section{The Key Reasons why Sexual Assault is a Huge Problem for Colleges and Universities Today}

The sexual assault crisis on college and university campuses did not happen overnight. There are several key factors 
that likely led to the current crisis: 1) the demise of the doctrine of in loco parentis; 2) a change in the definition of what constitutes sexual assault; 3) Greek Systems Perpetuating a "rape culture" on college and university campuses; and ultimately 4) the image problem created for schools that truthfully report the number of sexual assaults actually occurring on their campuses.

\subsection{The Doctrine of In Loco Parentis and its Demise}

For more than a hundred years, colleges and universities followed the doctrine of in loco parentis to handle student affairs. In loco parentis means "in the place of a parent." The doctrine allowed colleges and universities to enforce a conduct that among other things, limited contact between the sexes. Colleges and universities would require a "housemother" to patrol dorm rooms to ensure all students' doors were locked and dorms were separated by sex. This ensured that opportunities to drink alcohol and have sex were minimal at best. Given that the ability to drink and have sex was limited, the possibility for a sexual assault to occur was also limited. At the same time, there were still sexual assaults, but no one spoke about them (Glaser, 2014).

Over time, administrators and faculty moved towards treating students as adults and required them to be responsible for themselves. The focus of colleges and universities shifted from preventing sexual conduct between students to preventing sexual conduct between faculty and students. In giving students the space to be responsible for themselves, though, it seems that colleges and universities also effectively abdicated their responsibility to ensure that students were in a safe environment when they are at school (Perez-Pena \& Taylor, 2014). After all, these are still young adults and for many, this is their first time being on their own.

Since colleges and universities have eliminated the doctrine of in loco parentis as a method for controlling students and potentially preventing sexual assault, and have abdicated control of students to students themselves, universities are now left in a difficult position with respect to what their role is when a sexual assault does occur. The existing disciplinary systems of most institutions of higher learning do not allow administrators to effectively handle sexual assault cases because the disciplinary systems are not designed to deal with issues of sexual assault and have not been updated to handle these types of cases. Many administrators, staff, and faculty who investigate and decide these cases, while well trained in other student affairs issues such as plagiarism or fighting, are not well trained in how to resolve sexual assault cases. Sexual assaults are some of the most serious and potentially violent crimes. Colleges and universities are asking individuals with little to no training in sensitivity, forensic training or expertise in the issue of sexual assaults to investigate and adjudicate these cases (Glaser, 2014). David Lisak, a psychologist at the University of Massachusetts at Boston expertly notes the following: "It [mishandling of sexual assault cases] wouldn't be happening if we didn't have a 1,000 year system of failure dealing with sexual assault (Glaser, 2014)."

\subsection{The Current Definition of Sexual Assault}

The Federal Bureau of Investigation's ("FBI") current definition of rape states that rape is "penetration, no matter how slight, of the vagina or anus with any body part or object, or oral penetration of another person without the consent of the victim." The term sexual assault is broader and includes rape along with other forms of unwanted sexual contact. The authors chose to include the specific definition of rape in the paper because more than half of the sexual assaults reported meet the requirements for rape (Gray, 2014; Rubenfeld, 2014). Federal law takes the definition one step further by stating that sexual violence refers to a physical act perpetrated against a person's will or where a person is incapable of giving consent, including instances of rape, sexual assault, sexual battery, sexual abuse, and sexual coercion. Sexual Violence is a broad based term that includes potential causes of action such as rape and sexual assault. For purposes of this paper, the authors will refer to the term sexual assault to include all potential offenses under the umbrella of sexual violence (U.S. Department of Education, 2014). Both of these definitions are important because the laws have changed to ensure the victim must give consent to the sexual encounter. Why revise the definition of sexual assault to include consent? The government wanted to ensure that victims, who are so intoxicated that they cannot say no or are somehow otherwise incapacitated, are still protected. Nearly three-quarters of sexual assault victims in the one in five statistic pool were incapacitated. This only substantiates the role alcohol plays in these assaults. The issue of alcohol and sexual assaults will be discussed later in this paper (Gray, 2014).

While the definition of what constitutes sexual assault may seem straightforward, many schools are creating their own and dangerously overbroad definition. For example, Yale University's definition of sexual assault among students is any "nonconsensual sexual contact" where consent must be a prior "unambiguous agreement" to each "specific" touching, whether or not consented to in the past. Read literally, Yale's definition requires that students who choose to kiss one another must first come to an agreement regarding the kissing. Moreover, if two students are kissing and one student touches the other student's back without permission, sexual assault has been committed. Educational institutions are so nervous over the new definition of sexual assault, that schools are telling their students that having sex while intoxicated is always assault (Rubenfeld, 2014). 
These overbroad definitions of what constitute sexual assault are not only counter-productive, but also harmful. They equate violent sexual assaults with conduct that while still objectionable, is likely much less grave. Such definitions may discourage reporting because the adjudication process often ends without penalties or results in individuals being punished who have not actually committed assault. The bigger issue is that schools that utilize such broad based definitions because they do not truly understand what consent means, are likely failing to target the real offenders (Rubenfeld 2014). Most men in college do not rape or commit sexual assault. Research suggests that it is only a relatively small group of students who are repeat offenders. RAINN has cited evidence suggesting that ninety percent of college rapes are committed by just three percent of college men. This supports the notion that men who commit sexual assaults on college campuses are repeat offenders and these men are a very small percentage of men who attend institutions of higher education (Gray 2014; Rubenfeld, 2014).

The lack of understanding regarding what constitutes sexual assault has likely lead many universities to either have incredibly broad based definitions of sexual assault that make no sense, or simply put the issue on the backburner. Instead, schools need to better educate themselves with regard to the government's current definition. Moreover, schools must clearly define what constitutes sexual assault on their campuses and then educate students, staff, and faculty regarding these definitions. Failing to understand what constitutes sexual assault is simply not a good enough reason to ignore the problem.

\subsection{Collegiate Greek Systems Perpetuate a "Rape Culture" on College and University Campuses}

Women in sororities on college and university campuses are sexually assaulted at a higher rate than non-sorority women. A 2007 Oklahoma State University study determined that fraternity men are alarmingly three times more likely to commit rape than non-Greek men. Women in sororities are seventy-four percent more likely to experience rape than other college women. Moreover, a recent University of Oregon ("UO") study found that almost one in two members of sororities on UO's campus were victims of nonconsensual sexual contact. Fraternities are dangerous places for young women. Despite the UO study's findings, UO plans to expand their Greek system (both fraternities and sororities) on campus because of high demand amongst students (Robbins \& Florsheim, 2015; Valenti, 2014).

In many situations, fraternity culture may be ultimately to blame for the number of sexual assaults against sorority women. A Georgia Tech fraternity member sent an e-mail to teach fraternity brothers about "luring your rapebait" through pushing sorority women to drink to intoxication (Robbins \& Florsheim, 2015). In 2014, police began to investigate a University of Wisconsin fraternity after several women were found labeled with red and black x's on their hands after these women were hospitalized with memory lapses from intoxication at this fraternity house's party (Valenti, 2014).

A 2012 Colgate University study on campus binge drinking found that heavy drinking is "a symbolic proxy for high status in college," because it is "what the most powerful, wealthy, and happy students on campus do." The high status group was identified as "wealthy, male, white, heterosexual, and Greek affiliated undergraduates (Hess, 2013)." Moreover, one study found that sixty-two percent of individuals who commit sexual assaults "felt they had committed rape because of their alcohol consumption (Hess, 2013). These studies demonstrate that fraternity men associate their drinking with happiness and likely find their drinking excuses their sexual violence against women. Not all fraternities and fraternity men are sexual predators. For example, in her article, Frat Brothers Rape 300\% More. One in 5 Women is Sexually Assaulted on Campus. Should we Ban Frats?, Jessica Valenti notes that fraternities do tremendously vary with respect to how sexually dangerous they are to women. She finds that traditionally African-American fraternities, gender-inclusive fraternities, and multicultural fraternities are not as threating as those fraternities that are primarily white, economically entitled students. Still, something has to be done when such a large percentage of sexual violence involves one particular area of college and university life (Valenti, 2014).

The issue of higher rates of sexual assault amongst sorority women is more complex than fraternities who perpetuate rape culture and the fraternity men who rape. In her article, "Secrets of the Sisterhood," Alexandra Robbins identifies several key sorority actions that while certainly not the cause of sexual assaults may place sorority women at greater risk. Many students find that once they join a sorority, they are pressured to continually drink alcohol and interact with fraternities. These fraternity and sorority "mixers" as they are known, can turn into dangerous places for women. Robbins cites one student's account of a party at a North Carolina school where new sorority members were required to attend a fraternity party. According to the student, "It was definitely not a safe environment...[t]hey [the sorority] had this mentality of, "we have to impress these guys to increase the reputation of our chapter (Robbins \& Florsheim, 2015)."

Another risk factor for increased sexual assaults against sorority women may be the sororities ranking systems. Many women who join sororities are pressured by their peers to attend events with popular fraternities on campus to increase their rankings. Rankings are often dependent upon whether fraternities like a particular sorority (Robbins \& Florsheim, 
2015.).

Also a potential factor that may place women in the Greek system more at risk for sexual assault than non-Greeks is alcohol consumption (Robbins \& Florsheim, 2015.). Students attending schools with strong Greek systems tend to drink more than students at other types of schools (National Institute on Alcohol Abuse and Alcoholism, 2015). Moreover, the National Institute of Justice found that alcohol use and sexual assault are commonly linked on college campuses (National Institute for Alcohol Abuse, 2014.). Alcohol not only impairs judgment, but it can be used as a tool for sexual assault. In 2014, Brown University suspended a fraternity after a female student drank punch spiked with a date rape sedative and then reported that she was sexually assaulted (Schwartz, 2015). During Robbins interviews with sorority members, the women admitted there are fraternities on their campuses known to slip date rape drugs into the girls' drinks. Rather than report this behavior and ruin the sorority's reputation, the sorority women simply told their members not to "drink the punch (Robbins \& Florsheim, 2015)."

Sororities, while certainly not responsible for the high rate of sexual assaults amongst Greeks, have made excuses for fraternities in the name of maintaining their sorority's image. Many sorority women continue to attend events and party with fraternities whose men have sexually assaulted their sorority members. As one woman in Robbins article noted: "It's sad because people think it's the girl's job to defend herself and if she drinks the punch, that's her fault-instead of the sorority's fault for planning the mixer with that fraternity.... It's a system of everyone having to keep up this image that they're the best, the prettiest, the most fun. It's exhausting actually. I like my sorority, but I don't like the system (Robbins \& Florsheim, 2015)."

The National Panhellenic Conference ("the Conference") oversees collegiate sororities across the United States. While responsible for all these women and arguably their safety, the Conference has never studied and has no answer for why the rate of sexual assault is higher amongst sorority women than non-sorority women. Instead, in 2015, the Conference put together the Student Safety and Sexual Assault Awareness Task Force ("Student Safety Task Force"). The Student Safety Task Force provided a tool kit to sororities that contains resources, a hotline number, and guidelines for campus safety. The Conference has also said that it does not endorse rankings and that a strong reputation for a sorority comes from excellent grades and leaders, not hanging out with the most popular fraternity. The Conference's message about fraternity and sorority relationships, and the failure to investigate why sexual assaults are occurring at such a high level amongst sorority women, indicates a clear disconnect between those overseeing sororities and what is actually happening in sororities. Given that the Conference is tasked with overseeing some four million sorority members across the United States, this disconnect seems more than a little plausible (Robbins \& Florsheim, 2015).

The messages Greek men and women are receiving must change. Fraternities cannot continue to perpetuate rape culture and distance themselves from sexual assault under the guise of intoxication. As one member of a fraternity at George Washington University said: "It's just the way it is...We buy the alcohol, we serve the alcohol, they drink it. We all have a good time (Schwartz, 2015)." While a victim of sexual assault is in no way responsible for the assault, there are steps sororities can take to minimize the risk. Sororities can no longer rely on Fraternities for their social calendar and status. As one sorority member at the University of Michigan stated regarding why sorority women are forced to go to fraternity parties: “... [t]he whole social scene is embedded in the fraternity house, and makes us dependent on them. I find this a dangerous scenario (Schwartz, 2015)." Sororities must stop sending their women the message that if you do not attend fraternity events, interact with the "right" fraternities, and drink, you are not supporting your sorority and maintaining its image. Sororities need to reexamine their self-definition of what constitutes a successful sorority and work to minimize risk for their members.

\subsection{An Image Problem}

Higher Education is big business in the United States. In fall 2015, some 20.2 million students were expected to attend colleges and universities in the United States (National Center for Educational Statistics, 2015). The average annual price for each student's undergraduate tuition, fees, and room and board was $\$ 15,640.00$ for public institutions and $\$ 40,614.00$ for private nonprofit schools (National Center for Educational Statistics, 2015.). In addition, more and more donors are choosing to donate to their respective colleges and universities. In 2014, the Council for Aid to Education noted that some thirty-eight billion dollars were donated to institutions of higher education (Mulhere, 2015). Colleges and universities clearly have a vested financial interest in ensuring that students continue to enroll in high numbers at their respective institutions and donor relations remain strong.

Sexual assault cases on college and university campuses that are well publicized by the media can potentially affect university enrollment and donations. Because of this, institutions of higher education are seen as viewing sexual assaults as a public relations issue, rather than a safety issue (Dosenbury, 2015). In 2014, after Dartmouth University received a high number of sexual assault complaints, its application rate went down by fourteen percent compared to 2013 (Glaser 2015). Accordingly, colleges and universities have a serious conflict of interest when trying to handle 
allegations of sexual assault. While education institutions may have the best intentions in handling these cases, they are continuously faced with the notion that if more and more sexual assault cases are reported on campuses, the schools may have serious enrollment problems and donor decline

Critics have accused colleges and universities of "hiding" or "suppressing" victim reporting in an effort to appear as though they do not have a rape or sexual assault problem on their campuses (Dosenbury, 2015). Data from the Department of Education reveals that colleges and universities reported over five thousand sex offenses in 2013, but a recent study shows that the actual number is likely six times the original five thousand reported. Still, another survey reveals that some forty-one percent of colleges and universities have not conducted a single investigation into sexual violence claims in the past five years. Moreover, less than one-third of students that are found guilty of committing sexual assaults are expelled (Resource Center, 2015). These numbers start to demonstrate a pattern of "hiding" or "pushing the issue under the rug." As noted by Jaclyn Friedman, activist and co-editor of Yes Means Yes: "Trusting schools to quietly and voluntarily prevent sexual violence on campus has been tried for decades and it's failed." It fails because schools that succeed at suppressing victim reporting benefit from the impression that they don't have a "rape problem" while the more transparent schools' reputations (and donations) take a hit (Friedman, 2014).

Bonnie S. Fisher, a professor at the University of Cincinnati's School of Criminal Justice made the following comments on institutions of higher education and their handling of sexual assault cases: "It just hasn't been on most university administrator's agendas; they don't know how to approach it, and they just haven't taken the time to be informed. It's just another issue on their desks that they're hoping doesn't cause a loss of students or bad media attention." Ms. Fisher has authored some of the largest studies on campus sex crimes. As a result of universities largely ignoring the issue of sexual assault and sweeping these cases under the rug for fear of an "image problem," many women find themselves alone and feeling victimized by the very universities and colleges they trusted to protect them (Perez-Pena \& Taylor, 2014).

\section{Current Legislation, Its Effectiveness, and the Suggestions for Change}

\subsection{The Clery Act}

The Clery Act ("Clery"), passed in 1990 by Congress, was the first major piece of legislation to address the issue of sexual assault on college campuses. Clery requires institutions of higher education, that participate in federal student financial aid programs to publish annual reports on their respective security policies and campus crime statistics. These reports must be published to the colleges' and universities' campus community and the Department of Education (McCallion \& Feder, 2014; Gray, 2013 ). In addition to annual reports, Clery requires that colleges must collect and report data for the most recent three years in their Annual Security Reports. In addition to reporting crime statistics, Clery requires colleges and universities to implement a variety of safety and security measures. These measures must be included in the Annual Security Reports. Some examples of safety and security policies include: 1) policies regarding the procedures students and employees should use to report crimes; 2) a list of campus personnel and organizations to whom students and employees may report crimes that fall under the purview of the Clery Act; 3 ) policies for responding to incidents of sexual assault, domestic violence, dating violence, or stalking that have been reported to campus security or local police; 4) a daily crime log maintained by campus police or security that records all crimes reported. Annual Security Reports must be provided to all current students and staff and to any prospective student and/or staff that request the document U.S. Department of Education, 2014 (McCallion \& Feder, 2014).

In 2014, Clery was amended to include portions of the newly reauthorized Violence Against Women Act (Mahaffie, 2014). The amendments became effective on July 1, 2015 (U.S. Department of Education, 2014). Clery now requires colleges and universities to include all incidents of sexual violence in their required crime reporting statistics. Institutions of Higher Education are required to demonstrate in their reports what programs and policies they have implemented to prevent sexual assault on their campuses and what programs and policies they have in place to handle a sexual assault that occurs on their campuses. Moreover, Clery now mandates that institutions of higher learning provide the U.S. Government with what standard of proof is being utilized in their adjudication proceedings for sexual assault cases. Colleges must identify what policies and programs they have implemented to provide awareness to new students and employees and ongoing awareness and training for existing employees regarding the aforementioned (McCallion \& Feder, 2014).

In addition, Clery requires schools in their Annual Security Reports to verify that any victim of sexual assault was provided written notice regarding the options available to pursue her case with the university and/or seek assistance from local law enforcement. Finally, the newly amended Clery requires that university employees who handle, investigate, and adjudicate sexual assault matters, receive annual training on appropriately conducting investigations and adjudications to ensure the safety of the victim (McCallion \& Feder, 2014).

The Department of Education's Federal Student Aid office ("FSA") is tasked with ensuring that institutions of higher 
education comply with Clery reporting requirements. The FSA may remove colleges and universities from federal financial aid programs or impose fines up to thirty-five thousand dollars on colleges and universities that do not comply with Clery. While numerous schools have been investigated for potential Clery violations, no school has ever been removed from financial aid funding or fined (McCallion \& Feder, 2014).

\subsection{Systemic Implementation Issues with Clery}

In theory, Clery appears to be a piece of legislation that should combat and prevent sexual assaults on campuses. In practice, however, Clery has fallen short due to a number of loopholes that have left colleges and universities too much room for interpretation with respect to what Clery requires (Gray, 2014; McCallion \& Feder, 2014). Accordingly, institutions of higher education have come under fire due to allegations that many schools are underreporting sexual assaults on their campuses as required by Clery. For example, colleges can keep the incident of sexual assault within 'house' and use various techniques to keep the events off its Clery reports. University or college officials determine if the perpetrator has violated the schools' sexual misconduct policy. If a violation is found, the perpetrator may be disciplined through suspension, expulsion, or a variety of other methods. If the college or university, however, does not consider the incident a crime, then it will not count the incident in its Clery report. Institutional officials are often reluctant to refer sexual assaults to local authorities because they will then have to relinquish control of the situation and be subject to media scrutiny. Current policy guidelines, while requiring universities and colleges to let students know their right to report sexual assault to local enforcement, do not require universities and colleges to report sexual assault to local authorities or coordinate their investigation efforts with local law enforcement. Some states do have reporting requirements that require colleges and universities to report sexual assault to local law enforcement, but most do not. Moreover, even in states that require reporting to local law enforcement, universities and colleges still lead the investigation. This issue will be discussed in greater detail subsequently in this paper (American Association of University Professors (AAUP), 2013). Another example of using loopholes in Clery to underreport incidents by using tactics such as miscoding acquaintance rape as "non-forcible" and excluding off campus sexual assaults to avoid having to report (Gray, 2014).

Findings indicate that there is no consistency in the way sexual assaults are reported. Given that there are no consistent reporting requirements, questions arise with respect to the validity of the statistics collected by the Department of Education based on Clery reporting requirements. In turn, this raises questions regarding the Department of Education's ability to assess the extent of sexual assaults occurring across college university campuses and how these cases are being handled. As previously noted, if one in five women is being sexually assaulted on college campuses, there is simply no plausible way that seventy-seven percent of colleges and universities were reporting zero rapes in 2006 as revealed by a 2009 Center for Public Integrity study (McCallion \& Feder, 2014; Gray, 2014). The AAUP noted, in its 2013 report on "suggested policies and procedures for handling sexual assault on university campuses," that roughly two-thirds of campuses file Clery reports incorrectly. Two studies conducted by Heather M. Karjane and Christopher P. Krebs did find, however, that four-year colleges and universities and historically African-American colleges and universities are more likely to report correctly pursuant to Clery. Four-year public institutions of higher education tend to report more correctly than their private counterparts (AAUP, 2013). The studies, though, show many inconsistencies in proper reporting. The inconsistency in reporting pursuant to Clery was confirmed in a 2011 study by the Center for Public Integrity. The Center compared sexual assault data submitted by schools pursuant to Clery and data collected from sexual assault service and advocacy agencies connected to or near many of the same institutions. The Center found serious discrepancies in the numbers reported by the service and advocacy agencies versus the schools. Many cases of sexual assault reported by the agencies were omitted from colleges' and universities' Clery reports (AAUP, 2013). The lack of standardized reporting requirements, as well as underreporting by institutions of higher education, has led to the conclusion that better methodologies must be put into place to truly understand and combat the problem of sexual assault at institutions of higher learning.

\subsection{Title IX}

Title IX is a federal statute preventing institutions of higher education that receive federal funding from engaging in or allowing sex or gender discrimination on their campuses. Pursuant to Title IX, sexual harassment is considered a form of sex or gender discrimination when the "harassing conduct is severe or pervasive enough that it creates a hostile environment that interferes with a student's ability to access the educational program or activity in question (McCallion \& Feder, 2014)." In 2011 and 2014, the Department of Education released additional Title IX guidelines clarifying that any form of sexual violence is considered sexual harassment and is prohibited under Title IX. The term sexual violence refers to rape, sexual assault, sexual battery, and sexual coercion. All are considered forms of sexual harassment pursuant to Title IX (McCallion \& Feder, 2014). The guidelines note that one single incident of sexual violence may be sufficiently severe enough to create a hostile environment for the victim. The guidelines further require institutions to "take immediate action to eliminate the harassment, prevent its recurrence, and address its effects (McCallion \& Feder, 
2014)." In order to comply with these requirements, schools must take both preventative and remedial measures.

All colleges and universities, pursuant to Title IX, have an affirmative duty to prevent sexual assaults against their students. This requires schools to engage in several key activities including providing sexual harassment training to employees, adopting and publishing procedures for filing sexual assault claims (these procedures must identify timelines for investigation and provide for both parties to present evidence (McCallion \& Feder, 2014), educating students regarding sexual violence and their rights, and finally appointing a Title IX coordinator. Title IX coordinators and anyone involved in the sexual assault claim process must have training on how to apply the school's procedures and how to handle sexual assault claims (McCallion \& Feder, 2014). Title IX coordinators are responsible for coordinating Title IX compliance efforts, including coordinating any investigations of sexual harassment and sexual violence (U.S. Senate Subcommittee on Financial and Contracting Oversight (Subcommittee), 2014).

Title IX not only requires colleges and universities to prevent sexual assault, but also to respond quickly and effectively when a sexual assault does occur. The Department of Education has mandated that schools must investigate all sexual violence complaints and take steps to resolve these complaints. Schools are responsible to investigate complaints whether they occur on-campus or off-campus. While schools are required to notify victims that they may file a complaint with local law enforcement, schools must conduct their own investigations under Title IX regardless of whether law enforcement ultimately becomes involved (McCallion \& Feder, 2014).

Title IX guidelines require schools to engage in a number of other procedures to ensure that students are protected during the investigation and hearing process. Once a hearing is complete, an institution must provide the parties with written notice of the outcome. If a school does find that sexual violence has occurred and a "hostile environment" exists for the victim, the school must make every effort "to eliminate the harassment, prevent its recurrence, and address its effects (McCallion \& Feder, 2014)." Therefore, schools must not only discipline the perpetrator, but also find appropriate remedies for the victim. Victims should be provided counseling resources, different living arrangements, different class schedules, altered course work requirements, and referrals to sexual assault treatment centers as needed (McCallion \& Feder, 2014).

In addition to investigating sexual assault claims, Title IX requires colleges to adjudicate and resolve these claims. Title IX does not require schools to have a separate grievance procedure for sexual assault claims. Accordingly, while grievance processes vary from school to school, universities often use the same grievance process to resolve cases of plagiarism and sexual assault. While on the surface it may not seem problematic for a college or university to use its standard grievance procedure to handle sexual assault cases, the Subcommittee study paints a different picture. According to the Subcommittee study, many schools are simply not using best practices in adjudicating sexual assault cases. For example, the study found that for the nation's largest public and private colleges and universities, forty-three percent and thirty percent allow students to help adjudicate sexual assault cases. According to the study, a majority of experts believe that students should never participate in these hearings because it can raise privacy concerns for victims to detail such a painful experience to a peer and then have to see them in class or on campus. Even more disturbing is that approximately twenty percent of the nation's largest public institutions and fifteen percent of private institutions that allow athletics departments to oversee cases involving student athletes accused of sexual assault (Subcommittee, 2014).

Title IX allows for both enforcement of its requirements through the OCR and private action. A student, who has been sexually assaulted and believes a university or college has mishandled her case, may choose to file a complaint with OCR, file their own complaint in court, or do both. The burden of proof for cases filed by OCR, though, is significantly lower than for student-initiated lawsuits. If a student chooses to sue under Title IX individually, liability for student-on-student sexual harassment only attaches to the school if the school had actual knowledge of and was purposefully ignorant to the harassment. In contrast, if a student chooses to allow OCR to take action on their behalf, the school can be held liable for sexual harassment if the school knows or reasonably should have known about the student-on-student harassment, but failed to take immediate action to eliminate the harassment, prevent its recurrent, and address its effects (McCallion \& Feder, 2014).

Title IX requires all colleges and universities to have appropriate preventive and responsive measures in place to be in compliance. The Department of Education's Office of Civil Rights ("OCR") is tasked with ensuring that schools remain in compliance with Title IX. If a school is found to be out of compliance, OCR has significant discretion to negotiate settlements and remedies with colleges and universities. If no settlement is reached, the Office of Civil Rights has the ability to remove federal funding to schools that are not in compliance, although this has never been done (McCallion \& Feder, 2014; Anderson, 2014).

\subsection{Issues with Respect to Enforcement and Remedies under Title IX}

One major issue is OCR's lack of enforcement of Title IX. Title IX allows OCR to remove federal funding from schools 
that violate the law. Unfortunately, OCR has never actually removed federal funding from any school. OCR merely relies on the threat of removal to negotiate settlements with colleges and universities and bring them into compliance. Institutions of higher learning have become well aware that their federal funding is not going to be removed and the effectiveness of Title IX has potentially been eroded (McCallion \& Fedder, 2014; Anderson, 2014).

Title IX guidelines require that schools adopt a "preponderance of the evidence" standard in adjudicating sexual assault cases (Subcommittee, 2014). A preponderance of the evidence standard requires the college to determine that it is "more likely than not that the wrongdoing occurred (Anderson 2014)." This standard is typically used in civil litigation cases and is a much lower bar then the higher 'beyond a reasonable doubt' applied in criminal cases. Critics argue that alleged perpetrators are being deprived of their due process rights because the standard of proof is too low and a more stringent standard needs to be developed (Anderson, 2014).

Procedural due process guarantees that the government cannot engage in any action that would deprive a person of "life, liberty, or property without due process of law." The notion behind the law is that government cannot take away important interests from individuals, such as their freedom, without providing them fair and adequate procedures to contest the government's actions. Procedural due process is required in criminal proceedings because the accused could very well lose their freedom if they are found guilty (McCallion \& Feder, 2014).

Although critics make the procedural due process argument regarding Title IX, only public colleges and universities are subject to the constraints of procedural due process because the concept applies only to governmental action. While some states and common law may also provide for due process rights, most private colleges and universities are not subject to the concept of procedural due process. Contract law governs the relationship between a private university and students. Students are subject to the private university's code of conduct once they accept admission to the school (McCallion \& Feder, 2014).

Adjudication proceedings for sexual assault cases are more in line with civil proceedings and accordingly, should retain the current standard of proof. A hearing at a college or university based on sexual assault charges will not result in a loss of freedom for the accused. At most, the accused could be expelled from the institution. The accused's potential loss of rights is less significant and thus, a lower standard of proof, such as preponderance of the evidence is appropriate. Moreover, the Supreme Court has noted that the concept of procedural due process varies with a particular situation and has provided that "something less than a full evidentiary hearing is sufficient prior to adverse administrative action (McCallion \& Feder, 2014)."

\subsection{The Campus Accountability and Safety Act}

To address the issues surrounding Clery and Title IX, including colleges underreporting sexual assaults, lack of effective penalties for violations of Clery and Title X, and universities failing to comply with Clery and Title IX requirements, the Campus Accountability and Safety Act ("CASA") was introduced into Congress on February 26, 2015 (Stratford, McCaskill, et al., 2015). The U.S. Senate Subcommittee on Financial \& Contracting Oversight ("Subcommittee") conducted a survey of 440 four-year institutions of higher education regarding how colleges and universities report, investigate, and adjudicate sexual violence. The findings from this survey and interviews with stakeholders and three roundtable discussions were published on July 9, 2014. These findings would become the basis for CASA (U.S. Subcommittee on Financial and Contracting Oversight, 2014). CASA would close the loopholes that currently exist through amending Clery to ensure that all institutions of higher education are held more accountable for addressing sexual assault (Stratford, 2015; McCaskill, 2015; CASA 2015; Subcommittee, 2014).

CASA has several key components. The law would require schools to conduct bi-annual campus surveys of students to better identify and understand what is happening on college and university campuses with respect to sexual assault. Given that Clery statistics regarding sexual assaults are questionable as previously discussed, CASA seeks to confront this problem through a standardized survey that would be administered via an online portal (Stratford, McCaskill, et al., 2015; McCallion \& Feder, 2014; CASA, 2015; Subcommittee, 2014). The Subcommittee found in their study that while experts agree that annual confidential climate surveys regarding sexual assault are one of the best methods for obtaining accurate information regarding the number of cases of sexual assaults on college and university campuses, currently only sixteen percent of their national sample reported conducting climate survey. Even more unnerving is that only twenty percent of the nation's largest public schools and only twelve percent of the largest private schools conduct these types of surveys (U.S. Subcommittee on Financial and Contracting Oversight, 2014).

Colleges would be required to publish the results of the survey on their school websites and in their annual security reports. The Department of Education would be required to publish the names of all institutions of higher education currently under investigation for Title IX violations, the final resolution of these cases, and the agreements entered into by OCR and schools to resolve Title IX violations (CASA, 2015). CASA also requires institutions of higher education to designate confidential advisors to assist victims of sexual violence. Confidential advisors would be tasked with duties 
such as providing victims with support services, accommodations, guidance, and assistance with reporting crimes to the police.

The Subcommittee's report indicates that in their national sample, approximately twenty percent of schools still provide no sexual assault training for faculty or staff. This is an improvement from 2002, when forty-nine percent of schools provided no training. The Subcommittee notes, however, that the improvement is relatively small at best. Given that mishandling of sexual assault cases on campuses has become a serious problem, CASA mandates that anyone participating in the investigation, adjudication, and resolution of sexual assault cases receive specialized training. This ensures that those handling sexual assault cases do so with a better understanding of the nature of these crimes and the lasting effects on survivors (CASA, 2015; Subcommittee, 2014).

CASA delineates that all colleges and universities must use one uniform process for student disciplinary proceedings and coordinate their efforts to resolve cases with local law enforcement. As part of this effort, these institutions would no longer be allowed to have groups on campus, such as athletics departments, handle sexual assault cases. The Subcommittee found that many colleges and universities use a different adjudication process for collegiate athletes. The study found that more then twenty percent of institutions in the national sample gave their respective athletic departments oversight of sexual assault cases involving their student athletes. In examining the largest public and private colleges and universities, the Subcommittee found that twenty percent of the nation's largest public universities give athletic departments oversight of sexual assault cases involving student athletes and fifteen percent of the largest private institutions allow athletics departments' oversight (CASA, 2015). As part of one uniform process, campus officials must notify victims and the accused within twenty-four hours of deciding to pursue a case involving sexual assault. Schools must also enter into Memoranda of Understanding ("MOU”) with local law enforcement. MOU's delineate responsibilities of the two parties and require schools to share information with local law enforcement. Finally, CASA establishes harsher penalties for Clery and Title IX violations. As previously noted, current Title IX violations may result in a loss of federal funding, although OCR has never actually removed federal funding from a college or university. CASA requires that colleges and universities that do not comply with Title IX requirements may be fined up to one percent of the college or university’s operating budget, a much stiffer penalty. Penalties for Clery violations would increase from $\$ 35,000$ per violation to $\$ 150,000$ per violation (The Bipartisan Campus Accountability and Safety Act, 2015).

CASA is currently under consideration in the U.S. Senate. Should CASA become law, it will close the loopholes that exist in current legislation. CASA should also have a serious impact on how colleges and universities handle sexual assault cases and ensure that students are protected and treated fairly should they become the victims of sexual assault.

\subsection{Executive Action to Prevent Sexual Assault and Assist Victims}

In January 2014, President Obama signed the Presidential Memorandum establishing the White House Task Force to protect students from sexual assault. The Task Force established a website in April 2014 known as NotAlone.gov to provide information to students and schools on how to respond to and prevent sexual assault (Not Alone.Gova, 2015). On April 29, 2014, the Task Force published its first report with recommendations on how to protect students from sexual assault. The Task Force's report included many recommendations for improving how campuses respond to and prevent sexual assaults. Some of the key recommendations are detailed below (White House Task Force to Protect Students from Sexual Assault, 2014).

Similar to CASA, the Task Force requested that colleges and universities conduct climate surveys to understand the extent of sexual assaults on their respective campuses. The Task Force will provide a tool kit for developing and conducting these surveys. While currently the Task Force may only recommend surveys be conducted, they are looking into administrative or legislative options that would require colleges and universities to conduct these surveys. The Task Force also recommended that colleges and universities implement comprehensive and long term programs to educate students, faculty, and staff on responding to and preventing sexual assault. The Task Force provided information regarding effective prevention programs that colleges and universities could reference in preparing their own programs (White House Task Force, 2014). Some of these programs will be discussed in the recommendations section of this paper. Similar to CASA, the Task Force recommended that schools employ trained victims' advocates to provide emergency and ongoing support, such as contacting local authorities and providing counseling referrals. The Task Force has also chosen to provide sample reporting and confidentiality requirements to ensure that victims of sexual assault understand their rights with respect to confidentiality, reporting to local authorities, and responding to a sexual assault complaint. The Task Force put together a comprehensive checklist for schools to utilize in putting together easy to understand and effective sexual misconduct policies. Several entities, including the Department of Education and the Justice Department's Center for Campus Safety, have been tasked with preparing training materials for those who investigate and adjudicate sexual assault cases, and training for those who provide health services to victims. 
The Task Force has also put together sample MOU's for colleges and universities to utilize in partnering with local rape treatment centers and local law enforcement. An MOU with a local rape crisis or treatment center provides those handling sexual assault cases at colleges and universities a clear understanding of where they can send victims to receive counseling and other services after an assault has taken place. An MOU with local law enforcement is important because it creates an open line of communication between school officials and local law enforcement regarding what each entity is supposed to do when a sexual assault occurs and provides guidelines for how both entities can work together to investigate and effectively handle a case. The MOU's will make it much easier for victims to gain access to local treatment centers and provide better investigation coordination between schools and local law enforcement (White House Task Force, 2014).

Colleges and universities have an obligation to protect their students from sexual violence. The Task Force's guidelines, resources, and recommendations, provide schools with the tools they need to implement effective programs to prevent sexual assault, better assist victims, and provide a safer environment for all students. The question remains, though: Will institutions of higher education act given that these are only guidelines and not required processes or actions?

\section{Recommendations}

Colleges and universities today, can take more proactive measures and provide additional regulations to ensure their students are safe from sexual assault. Proactive measures include: 1) voluntary administration and publication of campus climate surveys and providing easier methods to report sexual assault;2) training for students on intervening in situations that could lead to a sexual assault; 3 ) more comprehensive sexual assault education programs for students; 4) alcohol education programs for students in conjunction with sexual assault education programs; 5) Focus sexual assault and alcohol education programs on the Greek System; and 6) harsher penalties for perpetrators of sexual assault. Additional regulations include: 1) sensitivity training programs for faculty and staff handling sexual assault matters on campus; and 2) mandatory reporting requirements to local authorities when a sexual assault happens on campus; schools that implement the aforementioned programs and regulations can stop sexual assaults, support those who have survived it, and bring perpetrators to justice (White House Task Force, 2014).

\subsection{Campus Climate Surveys and Simpler Methods for Reporting Sexual Assault}

The extent of sexual assaults on college campuses is relatively unknown. As previously mentioned, although Clery requires schools to report sexual violence on their college and university campuses, many schools are guilty of underreporting these crimes. In addition to schools underreporting, one study indicates that only two percent of incapacitated sexual assault survivors and thirteen percent of rape survivors actually report the crime to their respective campuses or local authorities (White House Task Force, 2013; Krebs, et al., 2007). The study found that there are a number of reasons victims underreport sexual assault. Many victims who are sexually assaulted by someone they know ("acquaintance rape") do not know that what has happened to them is sexual assault and they may blame themselves. Many victims fear how local authorities will treat them and they are concerned about the lack of proof in their cases. Moreover, many victims worry about their families finding out and they fear having to participate in a formal hearing process. One study found an astonishing forty percent of college and university victims feared retaliation from the perpetrator and did not report the sexual assault (White House Task Force, 2014; Sampson, 2002).

Educational institutions can and should play a critical role in breaking the cycle of violence and underreporting. To do this, however, colleges and universities must accept that they may have a problem on their campus with sexual assault and will have to publicly report these problems and create effective responses. Many school administrators find that by ignoring the problem, they appear to be a "safe campus" and are able to protect their spot in college and university rankings. By having a high ranking on these lists, colleges and universities appear to be more attractive to incoming students and donors. However, one must ask: is a college ranking more important than the safety of students at the university? The answer is clearly no.

One simple method to truly understand the extent of sexual assaults on any given campus is to conduct a campus climate survey (White House Task Force, 2014; CASA, 2015). Climate surveys can "gauge the prevalence of sexual assault on campus, test students' attitudes and awareness about the issue, and provide schools with an invaluable tool for crafting solutions (White House Task Force, 2014)." Moreover, because the surveys are anonymous, students will be inclined to provide accurate information. Climate surveys are most effective when given in winter or spring semesters, rather in than in the fall when students first arrive on campus (White House Task Force, 2014).

In addition to climate surveys, institutions need to do a better job of encouraging students to report sexual assault. One method that is both effective and simple is to provide students a twenty-four hour hotline to report incidents of sexual assault. A study of sexual violence on university campuses by the Subcommittee found that in 2014, only fifty-one percent of institutions provide a twenty-four hour hotline for reporting sexual assault. The study was based on a national sample of institutions. What is more encouraging is that seventy-three percent of the largest public institutions and 
eighty-two percent of the largest private institutions do provide a twenty-four hour hotline to report sexual assault. Still, the authors would argue that the numbers should demonstrate that one hundred percent of schools in the study provide a hotline (Subcommittee, 2014). Hotlines are needed at all institutions of higher education to provide students with a quick and easy method to report sexual assaults as soon as they happen. These hotlines will also allow people to report sexual violence anonymously, which may ultimately encourage more reporting of sexual assaults and better handling of these cases by universities and colleges.

In conjunction with having a twenty-four hour hotline, schools should also provide students with the ability to report incidents of sexual assault online. Despite the ease of setting up a website, the knowledge that most students are incredibly technologically savvy, and that most students use the internet for everything, The Subcommittee's national sample found that only forty-four percent of institutions reported providing students with the ability to report sexual assault online. Again, though, the largest public and private universities are doing a better job of providing students the ability to report sexual assaults online, with eighty-eight percent of the largest public universities and seventy-four percent of the largest private universities providing online portals for reporting (Subcommittee, 2014). Website reporting will allow students to report confidentially and anonymously, if needed. Moreover, a generation of students who have been raised using the Internet more often than not, may simply find it safer and easier to report sexual assault online.

\subsection{Bystander Intervention}

One of the most promising methods to combat sexual assault on campuses is bystander intervention. A bystander is "anyone who observes an emergency or a situation that looks like someone could use some help. They must decide if they are comfortable stepping in and offering assistance (Harvard University Offices of Sexual Assault Prevention \& Response, 2015)." In the context of sexual assault, bystander intervention is largely a common sense practice: "If a drunk young man at a party is pawing a drunk young woman, then someone nearby (the bystander) needs to step in (intervene) and get one of them out of there (Winerip, 2014)." While simple to understand, it can sometimes be difficult to implement. Studies show there are several key reasons why bystanders often do not intervene. One reason is that if there are several other people present, a bystander often believes the other people will help out and he or she does not have to help. Another reason is that situations are often ambiguous and difficult for a bystander to read. Bystanders often worry that they may have misjudged a situation or will be embarrassed if they intervene. Although harsh, some bystanders may also feel that a victim is somewhat responsible for his or her situation and will get what they deserve. Bystander intervention programs are designed to teach students how to overcome these thoughts and help out someone who is in need (Harvard University Office of Sexual Assault, 2015). Numerous universities are now implementing programs to teach students how to intervene and to encourage students to be good citizens by watching out for each other.

For example, in the past year, the University of Massachusetts (UMass) created a well-publicized bystander campaign. The program included bystander intervention training for four hundred and fifty resident assistants. The program also included public service videos and skits about sexual assault and intervention. The primary targets for the program are incoming freshman because they often tend to be prime targets for sexual assault. A study conducted by United Educators (an insurance company owned by many member colleges and universities) found that sixty-three percent of victims of sexual assault are freshman (Winerip, 2014). A vice chancellor overseeing the campaign at UMass noted that "the hope is that by giving intervention a formal name and linking it to a prescribed set of responses, when something goes wrong a light bulb will go off in students' heads, they will recognize what they are seeing and will remember what to do (Winerip, 2014)."

Training of students at UMass may have likely played a role in the apprehension of a rapist on the campus in the fall of 2014. Eight students intervened in a rape that was in process and prevented the woman from continuing to be assaulted. These students moved the victim to a safer area, called the police, and remained with the victim till police arrived (Winerip, 2014).

The University of New Hampshire has one of the most successfully developed research, training, and prevention programs for sexual violence in the United States. The program was developed in response to a brutal rape that occurred on campus in 1987. The University has an on campus rape treatment center. The school has created a center for evaluating and implementing bystander programs. In addition, the athletics department is required by the school to hold mandatory sexual assault education training sessions for varsity athletes. The program has worked. In 1987, thirty-seven percent of female students reported some form of sexual assault. By 2012, only sixteen percent reported some form of sexual assault (Gray, 2014; Winerip, 2014).

Research is just beginning to determine if bystander intervention programs are working, but the data appears encouraging. A University of New Hampshire study required a group of men to participate in a bystander intervention 
program similar to the University of Massachusetts' program discussed earlier in this paper. The study also included a group of men who did not receive the training. The study found that after several weeks, thirty-eight percent of men who received the training intervened in a sexual assault. Only twelve percent of the men who did not receive any training intervened. Another study conducted at Ohio University asked men four months after they received bystander intervention training if they had committed a sexual assault. Only 1.5 percent said they had. A group of men who received no training was asked the same question. 6.7 percent of these men admitted to committing a sexual assault (Winerip, 2014). The results from these studies demonstrate that if implemented correctly, bystander intervention programs can and do work.

For bystander intervention to be effective, students, both male and female, must understand that taking an intoxicated girl upstairs to a bedroom is not alright. Moreover, students need to recognize that a fellow student in need would welcome the intervention and assistance. If these messages become clear, bystander intervention can and will work. While many schools are implementing these programs, all schools in the U.S. need to implement training for bystander intervention. Empowering students in the art of bystander intervention can potentially be one of the most successful ways to combat sexual assaults on college campuses.

\subsection{More Effective Student Education Programs Regarding Sexual Assault}

The reauthorization of the Violence Against Women Act in 2014, provided amendments to the Clery Act that now require schools to provide sexual assault education and awareness programs to students and faculty. The amendments took effect this past July 2015. Not only must colleges and universities provide sexual assault education and awareness programs to students and faculty, but they must also detail what programs they provide to the Department of Education through their annual reporting of crime statistics pursuant to Clery (McCallion \& Feder, 2014). Simply having sexual assault prevention programs is not enough, though. These programs have to be effective.

The Centers for Disease Control and Prevention (CDC) conducted research concerning the most effective ways to reduce sexual violence on college campuses. Among its many findings, the CDC determined that effective sexual assault prevention programs are those programs that are "sustained, comprehensive, and address the root individual, relational, and societal causes of sexual assault." In other words, one brief educational program for incoming freshman on the topic of sexual assault is simply not enough. More must be done. The CDC has gone so far as to detail universities that have implemented effective programs to allow those schools that have not implemented sustainable programs the ability to compare notes (White House Task Force, 2014; Not Alone.Gov, 2015).

Some schools have stepped up to the plate to provide better sexual assault education for all students in the wake of increased pressure from the federal government and the national media attention the topic of sexual assault on college campuses is currently receiving. For example, George Washington University recently included in its orientation program mandatory small group discussion on issues related to sexual assault. Student activists have been pressuring the university for several years to implement such a program. Indiana University has gone several steps beyond George Washington. Last year, the University launched a sexual assault prevention initiative that approaches the problem from several different angles including: 1) more than 6000 posters with sexual violence definitions and resources placed in bathrooms across campus; 2) a new university website that provides students with all of Indiana's resources regarding sexual assault in one place, making it easier for students to utilize the system if a sexual assault occurs; and 3) finally, the university created the position of student welfare compliance coordinator to oversee some of the university's efforts to prevent and handle sexual assault cases. Rutgers University requires incoming freshman to attend a sexual violence presentation. This program has been in place for several years, but Rutgers has upped the ante by becoming the federal government's school of choice to pilot a new student climate survey to gauge students' experiences with rape on campus. UC Berkeley now requires incoming freshmen to complete an online sexual assault education program during summer orientation. Students are also required to participate in a sexual violence awareness program being offered for the first time. Berkeley has also chosen to involve its Greek system in the process by requiring new members entering the Greek system to engage in additional training about consent and victim blaming. Berkeley administration will also launch a public awareness campaign to inform students where they can go for help if they are assaulted (Culp-Ressler, 2014).

Schools such as those referenced above and others are trying to revamp their sexual assault education programs in an effort to prevent sexual assault. Change, however, is slow. A recent article indicates that activists are cautiously optimistic because of the national attention the issue of campus sexual assault is receiving. In addition, there is increasing pressure for college rankings to include information about how well a school handles rape cases. Moreover, students themselves are seeking out information regarding how a school handles these issues. All of this may result in more and more schools throwing out existing sexual assault education programs and instituting newer and more effective programs. Ultimately, in order for colleges to reduce the number of sexual assaults on their respective campuses, they must provide comprehensive and long-term programs to educate their students. 


\subsection{Combine Alcohol Awareness and Sexual Assault Education Programs}

A recent study conducted by the Harvard School of Public Health College concluded that there is a likely correlation between binge drinking and higher rates of sexual assault (Vries, 2014). In the study, binge drinking was defined for men as consuming five or more drinks in a row and for women as consuming four or more drinks in a row at least once in the past two weeks. The study was conducted over a period of three years and surveyed 119 colleges and universities across the United States. Some 24, 000 women were surveyed. The study found that nearly forty-four percent of study participants, both college men and women, could be classified as binge drinkers. The study also determined that colleges and universities with higher rates of binge drinking also had more sexual assaults (Vries, 2014).

Surveys, in addition to the Harvard study, have found that many college students who have been sexually assaulted say that they were under the influence of alcohol at the time and often, the perpetrators were under the influence, as well. (National Institute on Alcohol Abuse, 2015) These studies have also shown that an estimated 97,000 students between the ages of eighteen to twenty-four are victims of alcohol-related sexual assault or date rape (National Institute for Alcohol Abuse, 2015).

Recent interviews of students at Columbia University revealed that they had a range of opinions about the correlation between alcohol consumption and sexual assaults. While one student agreed that alcohol consumption and sexual assaults are a serious problem on college campuses, another disturbingly noted that “...[j]ust as a man might get too sexually aggressive when drunk, he said, a woman could also get more aggressive and a man might misinterpret that as meaning she wanted to have sex. The lines get really blurred." At the time of the interviews, the students had received only one fifty minute session during freshman orientation about sexual consent. Columbia has since made plans to change its freshman orientation education regarding sexual assault to two hours and have periodic sessions for students throughout their college career (Perez-Pena \& Taylor, 2014).

The aforementioned studies and statistics demonstrate that not only are better alcohol education programs needed at universities, but also the programs should be provided in conjunction with sexual assault prevention programs. If the two are potentially linked, as the studies indicate, then education on both topics together is essential. Henry Wechsler, director of the Harvard study noted the following:

"Because of the strong connection between alcohol and rape-and because of the findings that nearly three-quarters of the rapes that are reported are connected to alcohol and occur under the influence, when a women is unable to resist-we need to tie this topic to the alcohol prevention programs in college campuses, and particularly in universities where there is more drinking (Gardner, 2004)."

It should be noted that although there is a connection between alcohol and sexual assault, the authors are not and will never blame victims of sexual assault for the crime because of binge drinking. The decision of an individual to commit sexual assault is their decision alone, with or without alcohol. As Jaime Zuiback, a spokeswoman for the Rape, Abuse, \& Incest National Network said, “...In reality, the decision of the attacker to commit rape is the only cause of that crime ... [Rapists] alone are responsible for this decision to commit this heinous crime (Gardner, 2004)." There is no excuse for sexual assault regardless of whether a victim or their attacker is under the influence of alcohol.

And, colleges must do a better job educating students regarding alcohol consumption/binge drinking and sexual assault. Both topics need to be addressed together. Moreover, one session during a freshman orientation is simply not enough. Students need ongoing and more frequent education. While colleges and universities may not be able to stop binge drinking, they can education students. This may reduce the number of incidents of binge drinking and possibly, sexual assault. As universities and colleges implement better sexual assault prevention programs, they must bring the topic of alcohol consumption along for the ride.

\subsection{More Effective Training and Procedures for Investigating and Adjudicating Sexual Assault Cases.}

Title IX requires colleges and universities to investigate whether a sexual assault has occurred and if so, adjudicate the case to reach a final determination regarding the case. As previously noted in this paper, schools are not required to have a separate grievance procedure for sexual assault cases. These grievance procedures use honor codes designed to investigate plagiarism, fighting and drug use. These codes were not designed to address sexual assault (Winerip, 2014). Moreover, many tribunals or boards that handle sexual assault cases are made up of students, faculty, and administrators, who have little to no training on the issues surrounding sexual assault cases. A recent study indicates that some thirty-three percent of institutions of higher education fail to train people who investigate and adjudicate sexual assault cases. Robb Jones, senior vice president of United Educators (an insurance fund owned by more than twelve hundred colleges and universities), commented that those who serve on these tribunals are "... amateurs (Winerip, 2014).

Failing to properly train faculty, staff, and any other university officials that investigate and adjudicate sexual assault cases can be devastating. There is often a pervasive and culturally ingrained misunderstanding of what constitutes 
sexual assault-i.e., the difference between acquaintance rape and stranger rape, what constitutes rape itself, what does consent mean, and the severity of continued trauma to survivors after their attack (Subcommittee, 2014). Moreover, given that sexual assault crimes are some of the most serious crimes in the criminal code, it is difficult to understand how these cases can be handled by campus faculty, staff, and students who likely have no training in sensitivity, forensic training or any expertise in investigating a sex crime (Glaser, 2014). Without proper training, cases such as those of Emily Sulcowicz and Lena Sclove become all too common.

The federal government has detailed alternative models for universities to follow to better prepare those who investigate and adjudicate sexual assault claims. One such model is known as the single investigator model, where a trained investigator or several trained investigators interview the victim, the accused, witnesses, and gather physical evidence. These individuals then render findings, present a recommendation or work out an acceptance of responsibility agreement with the offender. This is clearly a different model than the standard collegiate judicial board hearing a case, making findings, and then rendering a verdict (White House Task Force, 2014). The federal government's initial findings indicate that innovative models such as the aforementioned encourage reporting of sexual assault and bolster students trust in the system significantly more than the standard judicial or adjudicative board process. These new models also safeguard an accused right to notice and right to be heard (White House Task Force, 2014; Anderson, 2014).

Whether schools utilize the models provided by the federal government or not, what is clear is that the process for handling sexual assault cases on college campuses needs to change. There must be appropriate training of faculty, staff, and administrators who handle sexual assault cases on what these types of cases entail, including, among other things, the differences between acquaintance rape versus stranger rape and what consent really means. Faculty, staff, and administrators must also receive sensitivity training concerning what truly happens to victims of sexual assault after the attack occurs. Victims of sexual assault may suffer from a variety of mental and health issues, including pregnancy, post-traumatic stress-disorder, depression, substance abuse, and more (McCallion \& Feder, 2014). Moreover, students should never play a role in investigating or adjudicating these cases. Schools must look into implementing some of the new methodologies for handling these cases as suggested by the federal government. In addition, an entirely separate grievance procedure for sexual assault cases should be implemented at schools. It is difficult to understand how a grievance procedure designed to handle cheating can effectively handle the crime of sexual assault. Our hope is that by providing faculty, staff, and administrators with better training, possibly new methodologies for investigating and adjudicating cases, and instituting separate grievance procedures, that victims and the accused will both receive a fair and impartial hearing and decision.

\subsection{Harsher Penalties for Perpetrators}

It is estimated that ninety to ninety-five percent of rapes on campuses are committed by fewer than five percent of male students. This indicates that recidivists are committing these sexual assaults. These are predators who find colleges and universities an environment where they can attack female students and escape punishment. Of those found responsible for committing sexual assaults, less than one third were expelled from their respective colleges or universities (Office of Kirsten Gillibrand, 2015; Gray, 2014). This is a small group of men, who somehow are allowed to remain on their respective campuses and continue to attack victims. A University of Massachusetts study found that only $6.4 \%$ of these men reported committing acts that fell under the legal definition of rape or attempted rape. Of those $6.4 \%$, more than half were repeat offenders. These individuals averaged almost six rapes per year. Other studies have reached the same conclusions (Gray, 2014). The statistic of college failure to adequately discipline perpetrators is further underscored by OCR's current investigation into some 101 colleges and universities for alleged Title IX violations related to the mishandling of sexual violence cases (Office of Kirsten Gillibrand, 2015).

There are many reasons why colleges do not properly discipline offenders in sexual assault cases. As previously noted, there is often a lack of appropriate training for faculty, staff, and administrators who investigate and adjudicate these sexual assault cases. Another potential cause is that at a number of colleges, departments such as athletics have oversight regarding sexual assault cases filed against their student athletes. These departments have vested interests in protecting their student athletes from suspension or expulsion (Subcommittee, 2014).

Another potential reason for institutions' failing to impart proper penalties for sexual assault cases may be the perceived connection between binge drinking and campus sexual assaults. As discussed earlier, surveys indicate that a majority of students who file sexual assault claims say that they were under the influence of alcohol at the time of the attack, and often their attackers were, as well (Perez-Pena \& Taylor, 2014). These cases can be murky, often a result of conflicting stories and alcohol consumption (Glaser, 2014). As a result, the focus seems to have shifted from catching and punishing recidivists to warning students to stop drinking. While warning students to stop drinking is certainly one method of reducing sexual assaults (as previously discussed in this paper), most men are not rapists and education will 
not prevent those men that are from attacking women, whether sober or under the influence of alcohol (Hess, 2013).

Wayne State University psychologist Antonia Abbey notes that colleges and universities can crack down on sexual assault by "increasing the 'risks' inherent in raping other people. If the costs of sexual assault are obvious, undesirable and immediate, then intoxication-driven sexual assaults are less likely to occur because the potential perpetrator cannot forget about the likely, undesirable consequences (Hess, 2013)." With respect to stronger penalties, the author advocates for expulsion of individuals found guilty of sexual assault. Currently, many colleges and universities use both suspension and expulsion to discipline those that have committed sexual assault. Approximately nineteen percent of institutions of higher education in the Subcommittee's national sample reported that they do not impose orders requiring the accused to avoid contact with the victim. What is encouraging, however, is that nearly all institutions, use suspension (ninety-four percent) or expulsion (ninety-seven percent) if a student is found guilty of committing sexual assault (Subcommittee, 2014). The authors, find, though, that suspension is not enough because it allows perpetrators the ability to return to campus and either come into contact with the victim or potentially sexually assault another student. While an investigation is ongoing, students suspected of committing sexual assault should be placed on leave from the university or college they attend until the conclusion of the case. Expulsion policies can easily be included in educational sessions on sexual assault. If potential perpetrators know what the consequences are going to be for committing sexual assault, they may think twice before committing the crime. A strong response to sexual assault demonstrates to both victims and assailants that such cases will be dealt with seriously by colleges and universities.

4.7 Mandatory Reporting Requirements and Cooperative Agreements between Institutions of Higher Education and Local Law Enforcement

Title IX requires colleges and universities to respond to sexual assault cases on their campuses because sexual assaults are considered a form of sex discrimination or sexual harassment. This includes conducting investigations and taking steps to quickly resolve a complaint. The current policy gives universities broad discretion with respect to how they investigate and resolve complaints (McCallion \& Feder, 2014). Current legislation does not require colleges to report sexual assaults to local law enforcement or work with local law enforcement to resolve these claims. The only requirements currently under Title IX with respect to local law enforcement are that universities contact local law enforcement to receive crime statistics for their ASRs and that victims be notified at the time of filing a complaint with the university or college that they have the right to report the crime to local law enforcement. The net result of these practices is that most schools have established their own procedures and policies for handling sexual assault cases (DeBold, 2014).

Colleges today vary greatly with respect to how they involve, if at all, local law enforcement in sexual assault cases on their campuses. Some universities have entered into voluntary memorandums of understanding (MOU) with local law enforcement. The MOU is often used to coordinate efforts between universities and local law enforcement with respect to handling sexual assault cases. These MOU, while different for every college that chooses to enter into one, often detail reporting procedures, investigative responsibility, information and resource sharing.

While some universities and colleges utilize MOUs extensively to work cohesively with local law enforcement to solve cases of sexual assault, many institutions pick and choose what they want local law enforcement involved in based on how the university categorizes particular crimes. For example, some institutions will delegate primary responsibility to local law enforcement to investigate forcible rapes on campus, but do not involve local law enforcement in acquaintance or date rapes. Given that date rapes are the most common form of sexual violence on college campuses, the usefulness of MOUS are seriously called into question (DeBold, 2014).

In recent years, some states have adopted laws that require cooperation between institutions of higher education and local law enforcement in handling sexual assault cases. For example, California's "Yes Means Yes" law requires that any reports of sexual assault, violent crime, or hate crime received by campus security personnel be immediately reported to local law enforcement. The laws accompanying Model Memorandum of Understanding ("MMOU") define best practices for collaboration between universities and local law enforcement. The MMOU requires institutions of higher education and local law enforcement to define their respective roles in handling sexual assault cases, requires both parties to work together to connect victims to support services, and requires regular sexual assault training for campus personnel and local law enforcement. The "Yes Means Yes" law also requires California's colleges and universities that receive state funded student financial aid to adopt a policy that defines what does and does not constitute consent to sexual activity (Peterson, 2015).

Similar to California, states like Washington, Minnesota, and Maryland have also passed legislation requiring schools to enter into MOUs with local law enforcement. Washington's states SB5518 also requires colleges and universities to conduct campus climate surveys to assess the prevalence of sexual assaults on their respective campuses. Similar to SB5518, Maryland's HB 571 also requires campus climate surveys to be conducted every two years (Peterson, 2015.). 
There is currently no federal legislation that requires all colleges to enter into MOUs (CASA is still pending legislation) (Campus Accountability and Safety Act, 2015). Accordingly, while requiring MOUs is an excellent means of defining the roles of both institutions of higher education and local law enforcement in resolving sexual assault cases, there are currently only a handful of states that require MOUs. Colleges in states that do not require MOUs are left to themselves to decide whether to work with local law enforcement or simply handle these cases on their own.

Victims, of course, still have the ability to report a sexual assault to local law enforcement. Most sexual assault victims, however, do not go directly to authorities. Instead, many victims report their sexual assaults to a campus faculty or staff member. Some may go to campus authorities. Unfortunately, the Subcommittee's report found that some thirty percent of law enforcement institutions do not receive training on how to respond to sexual assault (Subcommittee, 2014). These individuals then report the incidents to school administrators who often choose to handle these situations without the involvement of local authorities (Subcommittee, 2014). If colleges are not urging students to report acts of sexual violence or simply choosing to handle them in-house, the likelihood of a victim going to local authorities on their own is slim. Danielle Elizabeth Debold, writes in her article on the decriminalization of rape in America's college campuses that "[a] victim's decision to contact outside law enforcement often will be affected by her institution's initial treatment of her assault. If the institution does not treat the assault seriously or does not investigate and gather evidence that could help the victim corroborate her claim, she may be deterred from pursuing criminal charges (Debold, 2014)."

Schools must enter into MOUs with local law enforcement regarding sexual assault to protect their students. Colleges and universities cannot wait for state or federal legislators to pass legislation requiring them to do so. They must act now. MOUs should specify that colleges must report sexual assault cases to local law authorities. The MOU should also clearly delineate both the schools' and local law enforcements' roles in handling sexual assault cases, including which entity will primarily handle the sexual assault and how they will handle investigation and adjudication procedures. MOUs should also outline, similar to California's recent law, how both entities can not only work together to resolve the issue, but connect victims to support services, and provide regular training for campus personnel and law enforcement (Peterson, 2015). MOUs can only help universities better assist victims of sexual assault and quickly and effectively resolve these cases.

\section{Conclusion}

Sexual assault is a major issue facing colleges and universities today. Institutions of higher education can no longer sweep this issue under the rug and hope it goes away. There is no one single solution to resolve the issue of sexual assaults on college and university campuses. Multiple tactics must be employed to not only reduce the number of sexual assaults occurring today, but also to effectively address cases currently filed by victims.

With respect to reducing the number of sexual assaults, schools must first obtain accurate information regarding the number of sexual assaults occurring on their respective campuses. The authors urge colleges and universities to conduct confidential campus climate surveys to truly understand the sexual violence that is occurring on their campuses. Institutions of higher education must then implement long-term effective sexual assault and alcohol education programs that not only inform students about issues, such as what constitutes sexual assault, what is consent, what is considered binge drinking, but also the repercussions for committing an act of sexual assault. These programs must be well publicized on a regular basis and mandatory for all students not just entering, but also returning to college every year. Given that the number of sexual assaults is often higher amongst those in the Greek system, additional education should be provided to students entering the Greek system and those already in the Greek system annually. Colleges must also put funding towards implementing mandatory bystander intervention training programs for students. These training programs can simply become part of the sexual assault and alcohol prevention programs.

Not only should schools work to effectively prevent sexual assault from occurring, they must implement strategies and procedures to effectively resolve a sexual assault claim. Universities must provide annual training programs for faculty, staff, and administrators on better methodologies for investigating and resolving sexual assault claims. These trainings must include sensitivity training to appropriately be able to address victims, and a clear understanding of what constitutes consent and what constitutes sexual assault. Training should also provide faculty and staff with appropriate referrals for medical and rape crisis centers. Colleges must no longer allow students to participate in adjudicative proceedings or allow departments, such as athletics, to oversee sexual assa ult cases. Moreover, institutions of higher education should enter into MOUs with local law enforcement to require sexual assault to be reported to local authorities, and to utilize the local authorities' knowledge and resources to resolve sexual assault cases. Ultimately, schools must institute harsher penalties, such as mandatory expulsion for perpetrators of sexual assault.

For far too long, schools have ignored the problem of sexual assault on their campuses for fear of lower enrollment numbers and potential donor decline. Colleges and universities do not want their campuses to be seen as dangerous places. Accordingly, for many years schools have underreported incidents of sexual assault on their campuses. While 
the authors are hopeful that legislation such as CASA or potentially state legislative bills will pass and ultimately mandate that schools engage in the above referenced actions to prevent sexual assault and hold perpetrators accountable, schools cannot afford to wait. They must act now. Schools must choose to protect their students rather than focus on protecting their reputation. There is simply no other way.

\section{References}

American Association of University Professors (AAUP) (2013). Campus Sexual Assault: Suggested Policies and Procedures, 367-368. http://www.aaup.org/file/Sexual_Assault_Policies.pdf.

Anderson, N. (2014). Men Punished In Sexual Misconduct Cases On College Campuses Are Fighting Back, The Washington Post, 4.

Anderson, N. (2014). Tally of Federal Probes of Colleges on Sexual Violence Grows Fifty Percent since May, The Washington Post, 1-5.

http://www.washingtonpost.com/local/education/tally-of-federal-probes-of-colleges-on-sexual-violence-grows-50percent-since-may/2014/10/19/b253f02e-54aa-11e4-809b-8cc0a295c773_story.html.

Campus Accountability and Safety Act (CASA). (2015). https://www.congress.gov/bill/114th-congress/senate-bill/590/all-info\#major-actions.

Culp-Ressler, T. (2014). 11 Schools Taking Real Steps to Start Fixing The College Rape Crisis, Thinkprogess.org, 3-5. http://thinkprogress.org/health/2014/08/28/3476843/schools-sexual-assault/.

DeBold, D. E. (2014). The Decriminalization of Rape on America's College Campuses, National Association of Women Lawyers, 11, 12, 14.

Dosenbury, M. (2015). Unsurprising Study Finds Colleges Underreport Sexual Violence, Feministing, 1-2. http://feministing.com/2015/02/05/unsurprising-study-finds-colleges-underreport-sexual-violence/.

Friedman, J. (2014). An Image Problem, Time Magazine, 29.

Gardner, A. (2004). College Rapes Tied to Binge Drinking, Medicine.net, 2.

Gillibrand, K. (2015). Campus Accountability and Safety Act: Five Things to Know, 1. The Office of Kirsten Gillibrand.

Glaser, G. (2014). Why Colleges Fail at Investigating and Punishing Sex Crimes. L. A. Times, 1-3. http://www.latimes.com/opinion/op-ed/la-oe-glaser-college-sexual-assault-20140523-story.html.

Gray, E. (2014). Sexual Assault on Campus, Time Magazine, 2, 22, 23, 24, 26.

Harvard University Office of Sexual Assault Prevention \& Response (2015). What is Bystander Intervention?

Hess, A. (2013). To Prevent Rape on College Campuses, Focus on the Rapists, Not the Victims. Slate.com, 1-2. http://www.slate.com/blogs/xx_factor/2013/10/16/it_s_the_rapists_not_the_drinking_to_prevent_sexual_assault_o n_college_campuses.html.

Karjane, H. M., Fisher, B. S., \& Cullen, F. T. (2002). Campus Sexual Assault: How America's Institutions of Higher Education Respond. Final Report, NIJ Grant \# 1999-WA-VX-0008. Newton, MA: Education Development Center, Inc.

Kingkade, T. (2014, July 21). Brown University Becomes Latest Ivy League School under Federal Investigation, Huffington Post, 2. http://www.huffingtonpost.com/2014/07/21/brown-university-investigation_n_5606131.html.

Krebs, C., Lindquist, C., Warner, T., Fisher, B., \& Martin, S. (2007). The Campus Sexual Assault Study, http://www.ncjrs.gov/App/publications/abstract.aspx?ID=243011.

Mahaffie, L. B. (2014). Dear Colleague Letter, United States Department of Education.

McCallion, G., \& Feder, J. (2014). Sexual Violence at Institutions of Higher Education, Congressional Research Service, $1,3,5,8,9,10,12,17,18,19,21,22,24$.

McCaskill, C. (2015, February 26). Campus Accountability and Safety Act, campus.gov.

Mulhere, K. (2015). Deep-Pocket Donors, Inside Higher Ed., 1. https://www.insidehighered.com/news/2015/01/28/2014-record-year-higher-ed-donations.

National Center for Educational Statistics (NCES) (2015). Fast Facts: Back to School Statistics, 3. http://nces.ed.gov/fastfacts/display.asp?id=372.

National Institute on Alcohol Abuse and Alcoholism (2015). College Drinking, 2. www.niaaa.nih.gov. NotAlone.gov(a), last visited on August 22, 2015. https://www.notalone.gov. NotAlone.gov(b), Establishing Prevention 
Programming: Strategic Planning for Campuses, last visited on August $23,2015$. https://www.notalone.gov/assets/prevention-overview.pdf.

Perez-Pena, R., \& Taylor, K. (2014). Fight Against Sexual Assaults Holds Colleges to Account. The New York. Times, $1-7$. http://www.nytimes.com/2014/05/04/us/fight-against-sex-crimes-holds-colleges-to-account.htiml?_r+0.

Peterson, K. (2015). Recent State Laws: From “Campus Carry” to "Enough is Enough,” Campusclarity, 1.

Robbins, A., \& Florsheim, L. (2015). Secrets of the Sisterhood. MarieClaire, 148- 151.

Rubenfeld, J. (2014, May 26). Redefining Rape. Time Magazine, 28.

Sampson, R. (2002). Acquaintance Rape of College Students; Washington, DC: Office of Oriented Policing Services, U.S. Department of Justice.

Schwarz, A. (2015). Sorority Anti-Rape Idea: Drinking on Own Turf, The NY Times, 2. http://www.nytimes.com/2015/01/20/us/sorority-anti-rape-idea-drinking-on-own-turf.html?_r=0.

Stratford, M. (2015). Senator McCaskill and Others Renew Push on Campus Sex Assault, Make Changes to Bill, Inside Higher Ed., 1 .

https://www.insidehighered.com/news/2015/02/27/senator-mccaskill-and-others-renew-push-campus-sex-assaultmake-changes-bill.

Student Activism, Rape, Abuse and Incest National Network. https://rainn.org/get-involved/college. RAINN is the nations largest anti-sexual assault organization.

The Bipartisan Campus Accountability and Safety Act ("CASA”). (2015). http://www.gillibrand.senate.gov/imo/media/doc/CASA_One\%20Pager\%20(FINAL).pdf.

Todd, B. (2015). How Wagatwe Wanjuti Uses Social Media to Make College Campuses Safer, MsNBC, 1 .

U.S. Department of Education (2014). U.S. Department of Education Releases List of Higher Education Institutions with Open Title IX Sexual Violence Investigations, 2.

http://www.ed.gov/news/press-releases/us-department-education-releases-list-higher-education-institutions-open-ti tle-ix-sexual-violence-investigations. U.S. Department of Education, Violence against Women Act. Federal Register 62752, October 20, 2014.

U.S. Senate Subcommittee on Financial and Contracting Oversight (Subcommittee) (2014). Sexual Violence on Campus: How too Many Institutions of Higher Education are Failing to Protect Students, 2, 5, 6, 9, 10, 11, 12.

Valenti, J. (2014). Frat Brothers Rape 300\% More. One in 5 Women is Sexually Assaulted on Campus. Should we Ban Frats? The Guardian, 1-5. http://www.theguardian.com/commentisfree/2014/sep/24/rape-sexual-assault-ban-frats.

Vries, L. (2004). Binge Drinking, Rape are Related, CBS News, 1. http://www.cbsnews.com/news/binge-drinking-rape-are-related/

White House Task Force to Protect Students from Sexual Assault (2014).

Winerip, M. (2014). Stepping Up to Stop Sexual Assault, The NY Times, 1-10. http://www.nytimes.com/2014/02/09/education/edlife/stepping-up-to-stop-sexual-assault.html?_r=0

\section{(cc) Br}

This work is licensed under a Creative Commons Attribution 3.0 License. 